\title{
Ethnobotanical Plants Conservation by the Tribes of Amarkantak area of District Anuppur, Madhya Pradesh, India
}

\author{
Ganesh Singh Sandya ${ }^{1}$, Kumud Sandya ${ }^{2}$ \\ ${ }^{1}$ Department of Botany, Pt. S.N.S.Govt. P. G. College Shahdol - 484001 (India) \\ ${ }^{2}$ Department of Botany, Govt. Girls P.G. College, Shahdol - 484001 (India)
}

\begin{abstract}
The present paper deals with 25 plants species which are conserved by the tribes of Amarkantak district Anuppur Madhya Pradesh. Due to destruction of habitat, biotic interference and indiscriminate exploitation of natural plants, many valuable plant species of this area are fast disappearing. Aboriginals conserve these species by faiths, myths, taboos and religious aspects.
\end{abstract}

Keywords: Plant Conservation ,Ethnobotanical, Tribes , Amarkantak, Anuppur.

\section{Introductions}

Amarkantak area is one of the important tourists place in District Anuppur, Madhya Pradesh. This district is located in the central part of India. It is lying between $23^{\circ} 15^{\prime}$ to $24^{\circ} \mathrm{N}$ Latitude and $81^{\circ} 0$ ' to $81^{\circ} 45^{\prime} \mathrm{E}$ longitude. The total area of $3701 \mathrm{Sq}$. $\mathrm{Km}$ extends $80 \mathrm{Km}$. from east to west and $70 \mathrm{Km}$. from North to South. Several tribals asGond, Kondar, Kol, Baiga, Bharia, etc. are maintaining their culture and traditions since these cultures are influenced by scientific and economic changes, it is therefore, essential to study and conserve them before they become extinct. Madhya Pradesh still has the aboriginal tribals living in the forest as well as in the remote villages inhabited by so called higher castes. Since they are distributed mostly in the areas previously occupied by thick forest, they have learnt to use these habitats better for their living.(Figure 1)

A survey of literature indicates that Dwivedi (2003), Jain $(1963,1997)$, Khare (2001), Prajapati and Khare(2004),
Saxena and Tripathi $(1989,1990)$, Shah and Singh (1990) and Singh et al (2004) has made important contribution in this field.The tribals do not have any well defined conservation strategy of the kind we understand in modern terms. But they do conserve plants that are medicinally, economically, socially and culturally significant to them Their mode of conservation depends on faith and tradition.

\section{Material and Methods}

For the ethnobotanical study plant human interaction has to be observed carefully in the dynamic ecosystem in which they exist. The plants were collected by the investigator from the different study sites of Anuppur district during 2004-2005 by extensive field work. The queries were made as per plan suggested by Jain and Goel (1987) and the preservation methods were followed as prescribed by Agrawal (1983) and Ahirwar (2011).

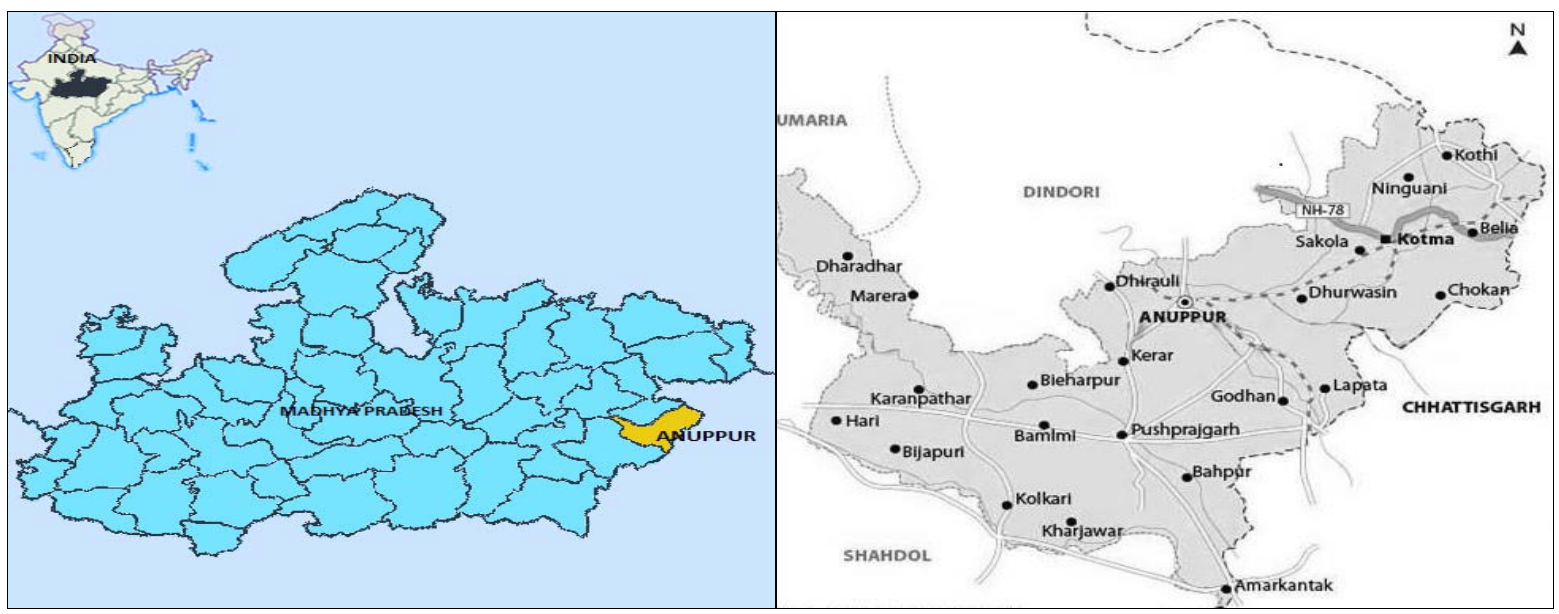

Figure 1: Location Map of Madhya Pradesh and study site District Anuppur 


\section{International Journal of Science and Research (IJSR) \\ ISSN (Online): 2319-7064 \\ Index Copernicus Value (2013): 6.14 | Impact Factor (2014): 5.611}

Table 1: Uses of Plant Conservation by the Tribes of Amarkantak area,District Anuppur, Madhya Pradesh,India

\begin{tabular}{|c|c|c|c|c|}
\hline S.No. & $\begin{array}{l}\text { Plant Name } \\
\text { (Local Name) }\end{array}$ & Family & \begin{tabular}{c|c|} 
Plant \\
part uses
\end{tabular} & Reason for Conservations \\
\hline 1. & $\begin{array}{l}\text { Achyranthus aspera } \\
\text { L.(Chirchita) }\end{array}$ & Amaranthaceae & $\begin{array}{c}\text { Root and } \\
\text { leaves }\end{array}$ & Roots are leaves are used in medicine. \\
\hline 2. & $\begin{array}{c}\text { Adina cordifolia Benth.\& } \\
\text { Hook (Haldu) }\end{array}$ & Rubiaceae & Wood & The wood is considered auspicious. \\
\hline 3. & $\begin{array}{l}\text { Aegle marmelos (L.) } \\
\text { Corr. }(\text { Bel })\end{array}$ & Rutaceae & Leaf & Sacred plant, the leaves are used to worship' Lord Shiva'. \\
\hline 4. & $\begin{array}{l}\text { Annona squamosa } \\
\text { (Sitaphal) }\end{array}$ & Annonaceae & Fruit, seed & For fruits and medicine. \\
\hline 5. & $\begin{array}{l}\text { Anthocephalus chinensis } \\
\text { (Lamk. }) \text { Rich.(Kadam). }\end{array}$ & Rubiaceae & $\begin{array}{l}\text { Whole } \\
\text { plant }\end{array}$ & Sacred plant, fruits are edible. \\
\hline 6. & $\begin{array}{l}\text { Azadirachta indica } \\
\text { Juss.(Neem) }\end{array}$ & Meliaceae & Leaf & $\begin{array}{c}\text { Plant is an abode of 'Marhi Mata' (The Goddess of small pox) Leaves are } \\
\text { used in medicines and pest control. }\end{array}$ \\
\hline 7. & $\begin{array}{l}\text { Boswellia serrata } \\
\text { Colebr.(Salaiya) }\end{array}$ & Burseraceae & Wood & The poles of wood are considered auspicious for wedding place. \\
\hline 8. & $\begin{array}{l}\text { Buchanania lanzan } \\
\text { Spr.(Char) }\end{array}$ & Anacardiaceae & $\begin{array}{c}\text { Fruits and } \\
\text { seeds }\end{array}$ & For fruits and seeds. \\
\hline 9. & $\begin{array}{l}\text { Butea monosperma } \\
\text { (Lamk.) Taub. (Palas) }\end{array}$ & Papilionaceae & $\begin{array}{c}\text { Leaves and } \\
\text { flowers }\end{array}$ & $\begin{array}{l}\text { Leaves are used for thatches, and the flowers are used to worship 'Lord } \\
\text { Jagannath. }\end{array}$ \\
\hline 10. & $\begin{array}{l}\text { Calotropis procera } \\
\text { Br.(Madar) }\end{array}$ & Asclepiadaceae & $\begin{array}{c}\text { Flowers } \\
\text { and fruits }\end{array}$ & The flowers and fruits are used to worship 'Lord Shiva'. \\
\hline 11. & $\begin{array}{l}\text { Erythrina suberosa } \\
\text { Roxb.(Handua) }\end{array}$ & Papilionaceae & Wood & The wood is considered auspicious for wedding place. \\
\hline 12. & Ficus bengalenis L.(Bar) & Moraceae & $\begin{array}{l}\text { Whole } \\
\text { plant }\end{array}$ & Sacred plant worshiped on 'Bara Barsat' festival. \\
\hline 13. & Ficus religiosa L.(Pipal) & Moraceae & $\begin{array}{l}\text { Whole } \\
\text { plant }\end{array}$ & The plant is considered on abode of 'Barsat 'festival. \\
\hline 14. & $\begin{array}{l}\text { Gymnema sylevestre ( } \\
\text { Retz.) R.Br.( Gurmar }\end{array}$ & Asclepiadaceae & Leaf & The leaves are used in medicine. \\
\hline 15. & $\begin{array}{c}\text { Holarrhena } \\
\text { antidysenterica Wall.( } \\
\text { Dudhi) }\end{array}$ & Apocynaceae & Bark & The bark is used for medicine. \\
\hline 16. & $\begin{array}{l}\text { Holoptelea intergrifolia } \\
\text { (Roxb.)Planch.(Chirol) }\end{array}$ & Ulmaceae & $\begin{array}{l}\text { Leaf and } \\
\text { Bark }\end{array}$ & Leaves are used as fish poison and bark is used in medicine. \\
\hline 17. & $\begin{array}{l}\text { Lawsonia inermis L. } \\
\quad(\text { Menhdi })\end{array}$ & Lythraceae & Leaf & The leaves are used for dye. \\
\hline 18. & $\begin{array}{c}\text { Madhuca longifolia } \\
\text { (Koen.)Mac. Br.(Mahua) }\end{array}$ & Sapotaceae & $\begin{array}{l}\text { Whole } \\
\text { plant }\end{array}$ & $\begin{array}{l}\text { Sacred plant, flowers used for liquor, and the wood is considered } \\
\text { auspicious. }\end{array}$ \\
\hline 19. & Mangifera indica L.(Aam) & Anacardiaceae & $\begin{array}{l}\text { Whole } \\
\text { plant }\end{array}$ & $\begin{array}{l}\text { For wood, leaves and fruits . The inflorences are offered to 'Lord Shiva' at } \\
\text { Mahashivratri festival. }\end{array}$ \\
\hline 20. & $\begin{array}{l}\text { Ocimum sanctum L. } \\
\text { (Tulsi) }\end{array}$ & Lamiaceae & $\begin{array}{l}\text { Whole } \\
\text { plant }\end{array}$ & Sacred plant, worshiped by girls for good groom. \\
\hline 21. & $\begin{array}{l}\text { Phoenix sylvestris Roxb. } \\
\text { (Khajri) }\end{array}$ & Araceae & Leaf, fruit & The fruits are edible and leaves are used to make headgear and brooms. \\
\hline 22. & $\begin{array}{l}\text { Emblica officinalis } \\
\text { L.(Amla) } \\
\end{array}$ & Euphorbiaceae & $\begin{array}{l}\text { Whole } \\
\text { plant }\end{array}$ & $\begin{array}{l}\text { Sacred plant, worshipped on 'Akshaya Navmi', fruits are eaten and used } \\
\text { in medicine. }\end{array}$ \\
\hline 23. & $\begin{array}{l}\text { Sterculia urens } \\
\text { Roxb. }(\text { Kullu })\end{array}$ & Sterculiaceae & $\begin{array}{l}\text { Whole } \\
\text { plant }\end{array}$ & The plant is conserved for gum, wood and medicine use. \\
\hline 24. & $\begin{array}{l}\text { Sterculia villosa } \\
\text { Roxb.(Udar) }\end{array}$ & Sterculiaceae & Root & The root is taken as a medicine. \\
\hline 25. & $\begin{array}{c}\text { Syzygium cuminii }(L) \\
\text { Skeels.(Jamun) }\end{array}$ & Myrtaceae & Fruits & Fruits are edible. \\
\hline
\end{tabular}

\section{Results and Discussion}

During study period is reported with 25 plant species, which are conserved by the tribals of Anuppur district for obvious reasons. These tribals organise various occasions and worship plants time to propitiate their gods and goddess. These traditions encouraged us to know their beliefs and ethnobotanical importance behind it. The botanical name of plants are alphabetically arranged, followed by their local name. All the data obtained as a sequence of present study has been reported.(Table 1)

\section{Acknowledgement}

The authors are thankful to tribal of this District in providing information about the plant species conserved by them. We express our gratitude to the Principal Dr. S. K. Saxenaof Govt. P. G. College, Shahdol (M.P.) for helpful suggestions and encouragement. 


\section{References}

[1] Agrawal, V.S.(1983). Perspective in Botanical Museum with species reference to India . Today and Tomorrow, New Delhi.

[2] Ahirwar, R.K. "Ethno medicinal plants studies in Jaitpur Forest Range of Shahdol District, Central India." Ad. plant Sci 24 (2011): 681-684.

[3] Ahirwar, Ramesh Kumar and Girja, Kumar Singh (2011) Some anti diabetic plants from Dindori District of Madhya Pradesh (India). Ind. J. Appl. pure Bio.26 (2) 269-271.

[4] Dwivedi ,S.N.(2003) . Etgnobotanical studies and conservational strategies of wild and natural resources of Rewa district of Madhya Pradesh , J .Econ. Taxon.Bot.. 27.

[5] Jain , S.K.(1963), Observations on ethnobotany of the tribals of Madhya Pradesh . Vanyajati11(4): 177-183.

[6] Jain , S.K. and A.K. Goel(1987) . Problem for field work . P. 171-183. In manual of ehthnobotany . Ed. S.K. Jain, Scientific publisher( India) Jodhpur.

[7] Khare, R.K. (2001) Study of ethnobotany among the tribals of Panna district with species reference to biodiversity. Ph. D . Thesis A.P.S. Univ. Rewa (M.P.)

[8] Prajapati , P.L. and P.K. Khare (2004) . Medicinal plants used by tribals of Panna district Madhya Pradesh (India) Plant Archives. 4:113-115.

[9] Saxena, S.K. and J.P. Tripathi(1989). Ethnobotany Bundelkhand I. Medicinal uses of wild trees by tribals inhabitants of Bundelkhand region . Jou Eco.Taxono.. Bot.14:263-170.

[10] Saxena, S.K. and J.P. Tripathi(1990). Ethnobotany Bundelkhand . II.Folklore therapy through herbs among inopulent parishioners and aboriginal tribes. Jou. Eco. Taxono. Bot.. ,14 :263-270.

[11] Shah , N.C. and S.C. Singh (1990), Hitherto unreported phytotherapeutical uses of tribals pockets of Madhya Pradesh, India , Ethnobotany, 2 : 91-95.

[12] Singh , Mrigendra Pratap, A.A. Khan and Shabina Khan (2004) . Medicinal plants of ethnobotanical importance curing. Jaundice from Maikal Hills( Amarkantak) Shahdol District .(M.P) India . Ad. Plant Sci., 17(1):4144. 